\title{
Thio Derivatives of $2(5 H)$-Furanone As Inhibitors against Bacillus subtilis Biofilms
}

\author{
E. Yu. Trizna ${ }^{1 *}$, E. N. Khakimullina', L. Z. Latypova', A. R. Kurbangalieva', I. S. Sharafutdinov', \\ V. G. Evtyugin', E. V. Babynin ${ }^{1}$, M. I. Bogachev², A. R. Kayumov ${ }^{1}$ \\ ${ }^{1}$ Kazan (Volga Region) Federal University, Kremlevskaya Str., 18, 420008, Kazan, Russia \\ ${ }^{2}$ St. Petersburg State Electrotechnical University, Prof. Popova Str., 5, 197376, St. Petersburg, \\ Russia \\ *E-mail: trizna91@mail.ru \\ Received 18.11.2014 \\ Revised manuscript received 09.02.2015 \\ Copyright $\odot 2015$ Park-media, Ltd. This is an open access article distributed under the Creative Commons Attribution License, which permits \\ unrestricted use, distribution, and reproduction in any medium, provided the original work is properly cited.
}

\begin{abstract}
Gram-positive bacteria cause a wide spectrum of infectious diseases, including nosocomial infections. While in the biofilm, bacteria exhibit increased resistance to antibiotics and the human immune system, causing difficulties in treatment. Thus, the development of biofilm formation inhibitors is a great challenge in pharmacology. The gram-positive bacterium Bacillus subtilis is widely used as a model organism for studying biofilm formation. Here, we report on the effect of new synthesized $2(5 H)$-furanones on the biofilm formation by B.subtilis cells. Among 57 compounds tested, sulfur-containing derivatives of $2(5 \mathrm{H})$-furanone (F12, F15, and F94) repressed biofilm formation at a concentration of $10 \mu \mathrm{g} / \mathrm{ml}$. Derivatives F12 and F94 were found to inhibit the biosynthesis of GFP from the promoter of the eps operon encoding genes of the biofilm exopolysaccharide synthesis (EPS). Using the differential fluorescence staining of alive/dead cells, we demonstrated an increased bacterial sensitivity to antibiotics (kanamycin and chloramphenicol) in the presence of F12, F15, and F94, with F12 being the most efficient one. The derivative F15 was capable of disrupting an already formed biofilm and thereby increasing the efficiency of antibiotics.
\end{abstract}

KEYWORDS antibacterial activity, biofilms; $2(5 H)$-furanones; Bacillus subtilis.

ABBREVIATIONS MIC - minimum inhibitory concentration; MBIC - minimum biofilm inhibitory concentration.

\section{INTRODUCTION}

It has now been established that in nature most bacteria exist in the form of specifically organized biofilms. Biofilms are a community of differentiated microbial cells tightly adhered to a substrate that are embedded in a polysaccharide matrix (EPS). This form of existence provides bacteria with a series of advantages under the influence of negative environmental factors and of the host organism. This leads, on one hand, to an increased efficiency of biotechnological processes and, on the other hand, to enhanced resistance to antimicrobial agents, antiseptics and disinfectants, and refractoriness to treatment, which results in an increased incidence of nosocomial infections and creates difficulties in microbiological diagnostics of infectious diseases [1$3]$. Therefore, biofilms represent a serious problem and require the development of drugs that disrupt bacterial biofilms and inhibit their formation on medical devices. Bacilli, gram-positive spore-forming rods, e.g., Bacillus anthracis and Bacillus cereus, which cause anthrax and severe foodborne toxicoinfections, also form biofilms on various surfaces [1]. B. subtilis cells are widely used as a model for studying bacillus biofilms [1].

Nowadays, bacterial biofilms are treated by coating surfaces with silver particles, immobilized enzymes disrupting the biofilm matrix, as well as various lowmolecular weight substances that act as inhibitors of biofilm formation genes [4]. Among these substances, a special place belongs to compounds of the $2(5 \mathrm{H})$-furanone series [5] that were firstly isolated from the red alga Delisea pulchra. Furanone derivatives have been shown to possess antimicrobial activity against a great number of gram-positive and gram-negative bacteria and inhibit biofilm formation $[5,6]$.

\section{EXPERIMENTAL}

Furanones

Figure 1 depicts the structures of the studied compounds: F12 - 5-hydroxy-4-[(4-methylphenyl)sulfonyl]-3-chloro-2(5H)-furanone [7], F15 - 4-benzyl-sulfonyl-5-hydroxy-3-chloro-2(5H)-furanone [8], and 
<smiles>Cc1ccc(SC2=C(Cl)C(=O)OC2O)cc1</smiles>

F12<smiles>O=C1OC(O)C(SCc2ccccc2)=C1Cl</smiles>

F15

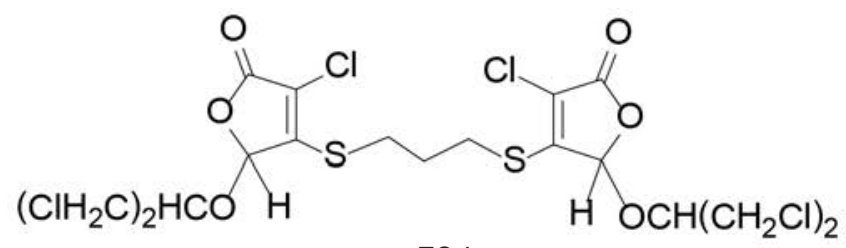

F94

Fig. 1. Structures of furanones that inhibit B. subtilis biofilm formation at a concentration of $10 \mu \mathrm{g} / \mathrm{ml}$

Table 1. Minimum furanone concentrations inhibiting B.subtilis 168 growth and biofilm formation; cyto- and genotoxic properties of the compounds

\begin{tabular}{|c|c|c|c|c|c|}
\hline \multirow{2}{*}{ Furanone } & \multirow{2}{*}{$\begin{array}{c}\text { Minimum inhibitory } \\
\text { concentration (MIC), } \\
\mu \mathrm{g} / \mathrm{ml}\end{array}$} & \multirow{2}{*}{$\begin{array}{l}\text { Minimum biofilm } \\
\text { inhibitory concentra- } \\
\text { tion (MBIC), } \mu \mathrm{g} / \mathrm{ml}\end{array}$} & \multirow{2}{*}{$\begin{array}{c}\mathrm{CC}_{50} \text { for } \mathrm{MCF}-7 \\
\text { cells, } \mu \mathrm{g} / \mathrm{ml}\end{array}$} & \multicolumn{2}{|c|}{$\begin{array}{l}\text { Genotoxicity of compounds (excess over } \\
\text { the control, times/cell number) }\end{array}$} \\
\hline & & & & Ames test* & SOS chromotest* \\
\hline F12 & 25 & 10 & 36.9 & $\begin{array}{c}2.4 \\
(109 \pm 25.2)\end{array}$ & 0.69 \\
\hline F15 & 25 & 10 & 65.7 & $\begin{array}{c}3.1 \\
(133 \pm 25.4) \\
\end{array}$ & 0.61 \\
\hline F94 & 50 & 10 & 83.9 & $\begin{array}{c}0.9 \\
(41 \pm 4.4)\end{array}$ & 1.09 \\
\hline Control $^{* *}$ & - & - & - & $\begin{array}{c}1.0 \\
(45 \pm 3.5)\end{array}$ & 1.00 \\
\hline $\begin{array}{l}\text { Positive } \\
\text { control*** }\end{array}$ & - & - & - & $8.2(369 \pm 15.6)$ & 22.71 \\
\hline
\end{tabular}

*Genotoxicity was evaluated at a $10 \mu \mathrm{g} / \mathrm{ml}$ concentration of furanones (corresponds to their MBIC values).

**Amount of dimethyl sulfoxide added in the form of a furanone solution.

***Sodium azide $(3 \mu \mathrm{g} / \mathrm{ml})$ and mytomycin $C(0.1 \mu \mathrm{g} / \mathrm{ml})$ were used in the Ames test and SOS chromotest, respectively.

Table 2. The effect of furanones on the thickness of a $B$. subtilis biofilm

\begin{tabular}{|c|c|c|}
\hline \multirow{2}{*}{ Furanone } & \multicolumn{2}{|c|}{ Biofilm thickness, $\mu \mathrm{m}$} \\
\cline { 2 - 3 } & $\begin{array}{c}\text { Cultivation with preliminary added furanones, } \\
96 \mathrm{~h}\end{array}$ & $\begin{array}{c}\text { Addition of furanones to the formed biofilm with } \\
\text { further incubation for } 24 \mathrm{~h}\end{array}$ \\
\hline Control & $10 \pm 1.6$ & $10 \pm 1.3$ \\
\hline F12 & $4 \pm 0.4$ & $6 \pm 0.3$ \\
\hline F15 & $2 \pm 0.3$ & $4 \pm 0.2$ \\
\hline F94 & $4 \pm 0.6$ & $8 \pm 0.7$ \\
\hline
\end{tabular}

F94 - 1,3-bis[3-chloro-5-(1,3-dichloropropane-2-yloxy)-2(5H)-furanone-4-ylsulfonyl]propane [9]; the compounds were synthesized according to the known techniques.

\section{Strains and culture conditions}

The following strains were used in the study: B. subtilis 168 [10]; B. subtilis K511 [11] carrying the gfp gene under the control of the promoter of the epsA gene, which is active during biofilm formation in B.subtilis.

The strains Salmonella typhimurium TA100 (HisG46, rfa, uvr-, pkm 101, bio-) [12] and S.typhimu- rium TA1535/pSK1002 [13] were used to test the compounds for mutagenicity.

All the bacterial strains were maintained and cultured in a LB medium (1.0 g/L of tripton; $0.5 \mathrm{~g} / \mathrm{L}$ of yeast extract; $0.5 \mathrm{~g} / \mathrm{L}$ of $\mathrm{NaCl}$; $\mathrm{pH}$ 8.5) [14]. Biofilm formation was determined using a BM medium (Basal medium), which is a modified SMM medium [15] supplemented with peptone to a final concentration of $7 \mathrm{~g} / \mathrm{L}$.

Biofilm staining with crystal violet

Biofilm formation was assessed in 96-well plastic plates (Cellstar Grenier bio-one No. 655 180) by stain- 
ing with crystal violet. Bacteria were cultured in $\mathrm{BM}$ at $37^{\circ} \mathrm{C}$ without shaking in wells containing 200 $\mu \mathrm{l}$ of the bacterial culture with an initial density of $3 \times 10^{7} \mathrm{CFU} / \mathrm{ml}$. After $72 \mathrm{~h}$ of incubation, the culture liquid was removed and the plates were washed once with phosphate-buffered saline (PBS) pH 7.4 and dried for $20 \mathrm{~min}$. Then, $150 \mu \mathrm{l}$ of a $0.1 \%$ crystal violet solution (Sigma-Aldrich) in 96\% ethanol was added per well and the plates were further incubated for $20 \mathrm{~min}$. The unbounded dye was washed off with PBS. The bound dye was eluted in $150 \mu \mathrm{l}$ of $96 \%$ ethanol, and the absorbance at $570 \mathrm{~nm}$ was measured on a Tecan Infinite 200 Pro microplate reader (Switzerland). Cell-free wells that were subjected to all staining manipulations were used as a control.

\section{Determination of the minimum \\ inhibitory concentration}

The minimum inhibitory concentration (MIC) of furanones was determined by broth microdilution method in the BM medium in 96-well plastic plates. The concentrations of furanones after serial dilutions were in the range of $0.1-500 \mu \mathrm{g} / \mu \mathrm{l}$. The wells were seeded with $200 \mathrm{ml}$ of the bacterial culture $\left(3 \times 10^{7} \mathrm{CFU} / \mathrm{ml}\right)$ in the $\mathrm{BM}$ medium and incubated at $37^{\circ} \mathrm{C}$. The minimum inhibitory concentration was determined as the lowest concentration of furanone for which no visible bacterial growth was observed after $24 \mathrm{~h}$ of incubation. The minimum biofilm inhibitory concentration (MBIC) was determined as the lowest concentration of furanone that completely inhibited biofilm formation after $72 \mathrm{~h}$ of growth.

Determination of the geno- and cytotoxicity of furanones

The mutagenicity of furanones at the MBIC concentration was evaluated in the Ames test [12]. We used the dimethyl sulfoxide (DMSO) solvent as a negative control and sodium azide $\left(\mathrm{NaN}_{3}\right)$ as a positive control. A tested compound was considered to be mutagenic if the number of revertant colonies in the experiment was more than 2 times higher than that in the control (solvent). The DNA-damaging activity of the compounds was evaluated in the SOS chromotest using the $S$. typhimurium TA1535/pSK1002 strain [13]. The overnight bacterial culture was diluted 10 times with a LB medium and grown in the presence of the study compounds for $4 \mathrm{~h}$. Next, the cells were collected by centrifuging and the $\beta$-galactosidase activity was determined according to [16]. Cytotoxicity of the compounds was determined using the MTS test (Promega) on MCF-7 cells, and the median cytotoxicity concentration $\mathrm{CC}_{50}$ (the concentration required to reduce cell activity by $50 \%$ ) was calculated.
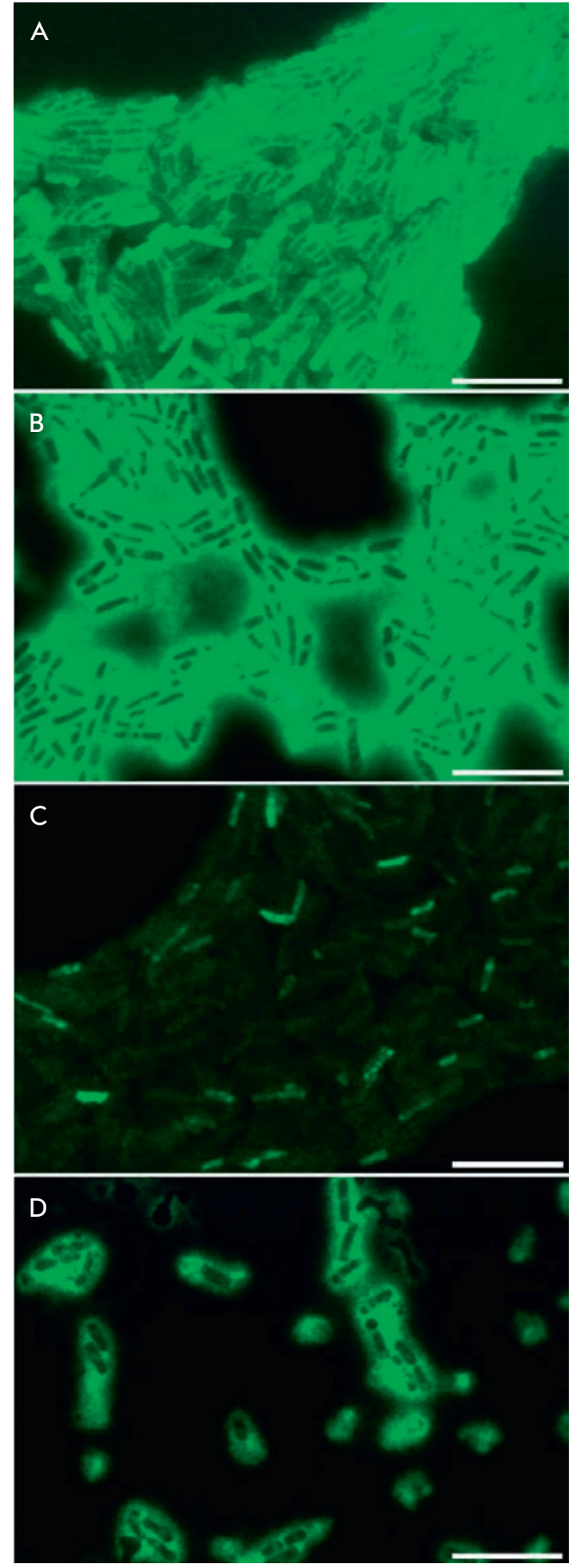

Fig. 2. The effect of furanones on the fluorescence intensity of GFP expressed from the eps operon promoter in $B$. subtilis $\mathrm{K} 511$ cells. Cells were grown in the presence of F12 (B), F15 (C), and F94 (D) at a concentration of $10 \mu \mathrm{g} / \mathrm{ml}$ (corresponds to MBIC) for $72 \mathrm{~h}$. Cells grown in the absence of furanones were used as a control $(A)$. The scale bar is $10 \mu \mathrm{m}$ 

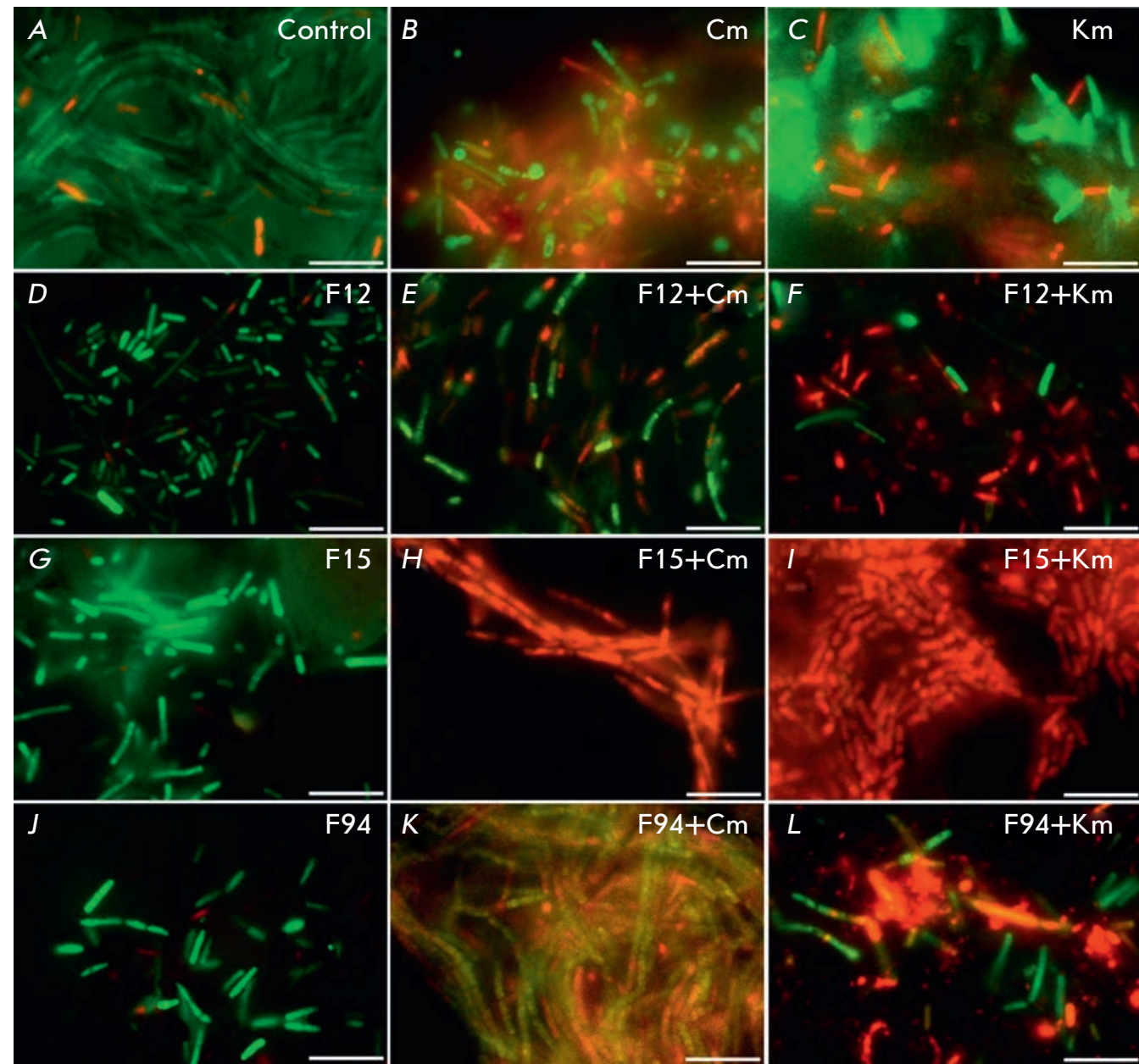
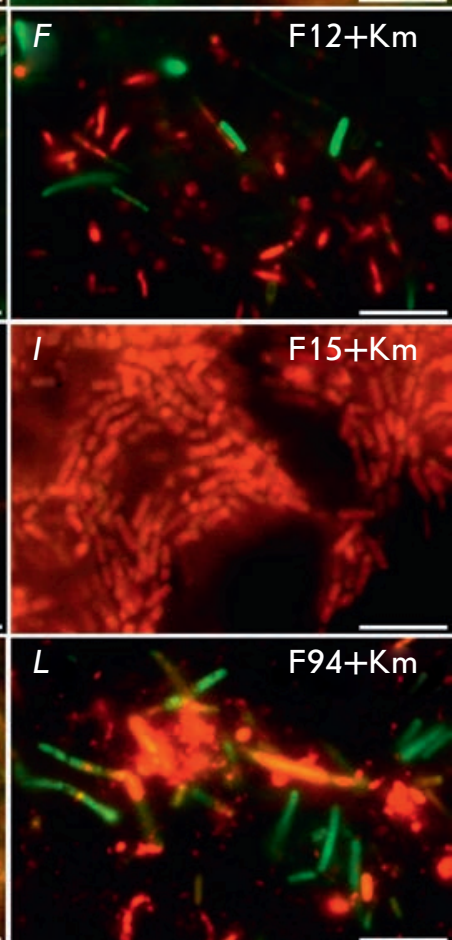

Fig. 3. The effect of furanones on biofilm formation by $B$. subtilis cells and the sensitivity of $B$. subtilis cells adhered to the culture plate surface to antibiotics. B. subtilis 168 cells were grown for $72 \mathrm{~h}$ to form a biofilm in the absence ( $A$, $B, C)$ or presence of furanones $(D, G, J)$ at a concentration of 10 $\mu \mathrm{g} / \mathrm{ml}$ (corresponds to MBIC). Then, chloramphenicol $(\mathrm{Cm})$ $(E, H, K)$ or kanamycin $(\mathrm{Km})(F, I, L)$ was added. After $24 \mathrm{~h}$ of incubation with an antibiotic, the number of viable cells was analyzed by staining the cells with propidium iodide and fluorescein diacetate. The scale bar is $10 \mu \mathrm{m}$

\section{RESULTS AND DISCUSSION}

Earlier, we identified halogen- and sulfur-containing derivatives of $2(5 \mathrm{H})$-furanone that inhibited B. subtilis biofilm formation [6]. Additional screening of 56 substances enabled the identification of two more furanones (F15 and F94) inhibiting the biofilm formation at a concentration of 10 $\mu \mathrm{g} / \mathrm{ml}$ (Table 1). F2 and F8 (5-hydroxy-4-[(4-methylphenyl)sulfonyl]-3-chloro-2(5H)-furanone and 3,4-dichloro-5-[(1,3-dichloropropane-2-yloxy)]-2(5H)-furanone, respectively), which were characterized in reference [6], increased the activity of the genetic competence system of $B$. subtilis and were not included in further research. F15 and F94 did not increase the activity of the transcription factor ComA, which activates the system of genetic competence development in $\mathrm{Ba}$ cilli (not shown).

In order to establish the influence of furanones on the expression level of the eps operon encoding biofilm EPS synthesis genes, B. subtilis K511 cells carrying the $g f p$ gene under control of the epsA gene promoter were grown in a BM medium in the presence/absence of furanones for $72 \mathrm{~h}$ and analyzed using a fluorescent microscope (Fig. 2). Detection of GFP in the cells in the absence of furanones indicated expression of the eps operon and production of EPS, which is the biofilm matrix basis (Fig. 2A). GFP was not identified in the presence of furanones F12 and F94, suggesting the repression of EPS production and, as a consequence, the repression of biolfilm formation in the presence of these compounds (Fig. $2 B, D)$. Apparently, the molecular targets for these compounds are the regulatory pathways of organism adaptation to stress conditions. Indeed, F12 was demonstrated to inhibit the activity of the transcription factors Spo0A and TnrA [6]. On the contrary, GFP was also detected in the presence of F15, although in substantially lower amounts compared to the control; therefore, no suppression of the eps operon occurred. It is possible that F15 inhibits the biofilm formation through a different pathway, without involvement of the eps operon regulation. 

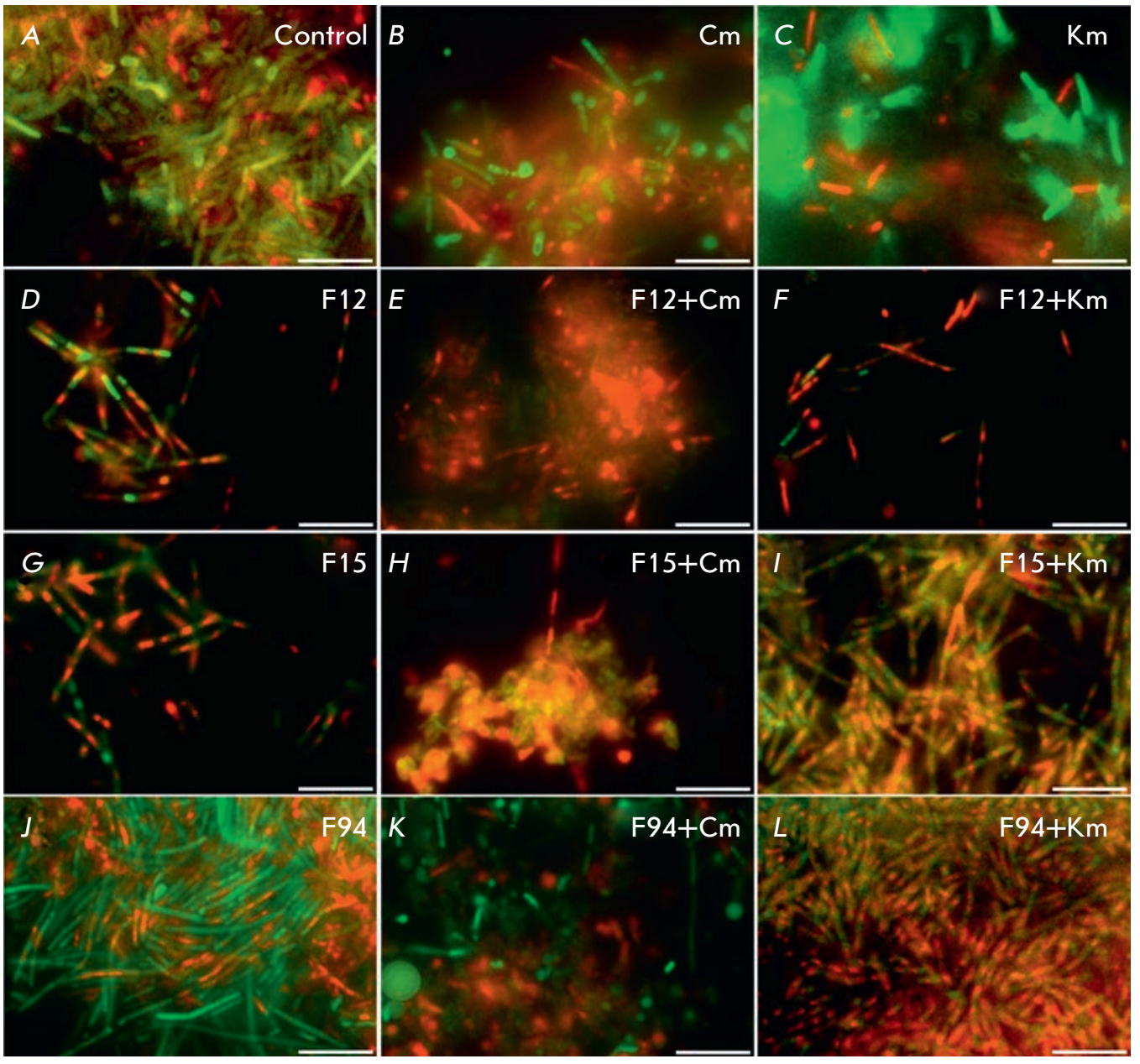

Fig. 4. Furanones

disrupt a biofilm and increase the efficiency of antibiotics against biofilm-embedded B. subtilis cells. B. subtilis cells were cultured for $72 \mathrm{~h}$ to form a biofilm $(A, B, C)$. Then, furanones were added to a final concentration of $30 \mu \mathrm{g} / \mathrm{ml}$ (threefold excess of $M B I C)(D, G$, $J)$ in the presence of chloramphenicol $(\mathrm{Cm})$ $(E, H, K)$ or kanamycin $(\mathrm{Km})(F, I, L)$. After 24 $h$ of incubation with an antibiotic, the number of viable cells was analyzed by staining the cells with propidium iodide and fluorescein diacetate. The scale bar is $10 \mu \mathrm{m}$
Furanones increase the sensitivity of adhered cells to antibiotics

Antimicrobial agents are known to be ineffective against bacteria in the biofilm mode of existence. Presumably, the repression of biofilm formation should increase the efficiency of antimicrobial agents. Potential synergism between furanones and antibiotics was studied using the chessboard method, where the furanone and antibiotic (kanamycin and chloramphenicol) concentrations were varied from 0.1 to 2.0 MIC [17]. However, no compound exhibited synergism with antimicrobial agents with respect to plankton cells $(\mathrm{FIC}=$ $1.2 \pm 0.21)$.

In order to investigate whether furanones increase the sensitivity of surface-adhered bacteria to antibiotics, Bacilli were grown in a BM medium in the presence of furanones at a $10 \mu \mathrm{g} / \mathrm{ml}$ concentration (MBIC) for $72 \mathrm{~h}$, then antibiotics (chloramphenicol and kanamycin) were added to a final concentration of $10 \mu \mathrm{g} / \mathrm{ml}$ (established MIC values were $2.5 \mu \mathrm{g} / \mathrm{ml}$ ). After $24 \mathrm{~h}$ of cultivation, the culture liquid was removed, the biofilm was washed once with PBS, and differential fluorescent staining with propidium iodide and fluorescein diacetate was performed to identify dead and alive cells, respectively, in the layer of microbial cells adhered to the culture plate surface. The obtained specimens were analyzed using a Carl Zeiss Axio Imager 2.0 fluorescent microscope (Fig. 3).

The formation of a biofilm up to $10 \mu \mathrm{m}$ thick was observed in the control sample (Fig. 3A, Table 2). In this case, addition of chloramphenicol (Fig. 3B) or kanamycin (Fig. $3 C$ ) resulted in the death of only a small fraction of the adhered cells. In contrast, in the culture grown in the presence of $\mathrm{F} 15(10 \mu \mathrm{m} / \mathrm{ml})$, the biofilm thickness was $2 \mu \mathrm{m}$, and addition of an antibiotic resulted in almost complete death of bacilli (Fig. $3 \mathrm{H}, \mathrm{I}$ ), while furanone itself had no bactericidal effect (Fig. $3 G$ ). In case of F12 and F94 at the concentration of 10 $\mu \mathrm{g} / \mathrm{ml}$, the effect was less pronounced. Thus, the presence of furanones in the culture medium inhibited biofilm formation on the culture dish surface and increased the efficiency of the antibiotics, apparently due 
to a longer exposure of bacterial cells to antimicrobial agents.

The possibility of bacterial biofilm disruption in the presence of furanones was also studied. For this purpose, we grew B. subtilis cells in a BM medium for 72 $\mathrm{h}$, removed the culture liquid, and added a pure BM medium supplemented with furanones $(30 \mu \mathrm{g} / \mathrm{ml})$, kanamycin, and chloramphenicol. After $24 \mathrm{~h}$, the residual biofilm was washed with PBS and differential fluorescent staining was performed (Fig. 4).

As in the previous experiment, antibiotics in the absence of furanones were found to be ineffective against the cells embedded in the biofilm matrix (Fig. 4B, C). Supplementation with F12 $(30 \mu \mathrm{g} / \mathrm{ml})$ caused significant biofilm disruption after $24 \mathrm{~h}$ (Table 2), and addition of antibiotics caused the death of the vast majority of cells (Fig. 4D-F). In this case, the effect of F15 was less pronounced, while F94 caused almost no increase in the sensitivity of the cells to the antibiotics and did not lead to biofilm disruption (Fig. 3G-L).

Cyto- and genotoxic properties of

compounds F12, F15, and F94

Determination of the cytotoxicity of F12, F15, and F94 showed that their $\mathrm{CC}_{50}$ values were 7 times higher than the concentrations necessary to inhibit biofilm formation (Table 1). Although the SOS chromotest did not detect the DNA damaging activity of the compounds, the Ames test data indicated potential mutagenicity of F12 and F15.

\section{CONCLUSIONS}

Thus, the thio-containing compounds F12 and F15 may be of interest for further development of furanone-based inhibitors of bacterial biofilms. However, the potential mutagenicity of these furanones revealed in the Ames test serves as a contraindication for their direct application and requires further modification of their structure.

The research was performed using the equipment of

Interdisciplinary center for collective use of Kazan

Federal University supported by Ministry of Education of Russia (ID RFMEFI59414X0003)

This work was supported by the Governmental Program on Improvement of Competitiveness of the Kazan (Volga Region) Federal University among the world's leading research and education centers, the Ministry of Education and Science of the Russian Federation (contract № 2014/187), and by the Russian Foundation for Basic Research (grant № 14-04-31635 mol_a).

\section{REFERENCES}

1. Vlamakis H., Chai, Y., Beauregard P., Losick R., Kolter R. // Nat. Rev. Microbiol. 2013. № 11. P. 15-168.

2. Kayumov A.R., Balaban N.P., Mardanova A.M., Kostrov S.V., Sharipova M.R. // Microbiology. 2006. V. 75. № 5. P. 557-563.

3. Schmidt T., Ziganshin A.M., Nikolausz M., Scholwin F., Nelles M., Kleinsteuber S., Pröter J. // Biomass Bioenergy. 2014. V. 69. P. 241-248.

4. Ma Y., Xu Y., Yestrepsky B.D., Sorenson R.J., Chen M., Larsen S.D., Sun H. // PLoS One. 2012. P. 1-10.

5. Lonn-Stensrud J., Landin M.A., Benneche T., Petersen F.C., Scheiel A.A. // J. Antimicrobial Chemotherapy. 2009. № 63. P. 309-316.

6. Kayumov A.R., Khakimullina E., Sharafutdinov I., Trizna E., Latypova L., Hoang L., Margulis A., Bogachev M., Kurbangalieva A. // J. Antibiotics. 2014. № 143. doi:10.1038/ ja.2014.143 (epub ahead of print)

7. Kurbangalieva A.R., Devyatova N.F., Bogdanov A.V., Berdnikov E.A., Mannafov T.G., Krivolapov D.B., Litvinov I.A., Chmutova G.A. // Phosphorus, Sulfur, Silicon, Relat. Elem. 2007. V. 182. № 3. P. 607-630.

8. Latypova L.Z., Saygitbatalova E.Sh., Chulakova D.R., Lodochnikova O.A., Kurbangalieva A.R., Berdnikov E.A.,
Chmutova G.A. // Rus. J. Org. Chem. 2014. V. 50. Is. 4 P. 532-545.

9. Khoang T.L., Khaziev R.M., Zaripova A.R., Kurbangalieva A.R., Chmutova G.A. // Book of Abstracts of the III AllRussian Scientific Conference "Progress in Synthesis and Complex Formation”. Moscow, April 21-25, 2014. Moscow: RUDN, 2014. P. 205.

10. Kayumov A., Heinrich A., Sharipova M., Iljinskaya O., Forchhammer K. // Microbiology. 2008. V. 154. P. 23482355.

11. Kobayashi K. // Mol. Microbiol. 2008. № 69. P. 1399-1410.

12. Ames B.N., McCann J. // Ann. N.Y. Acad. Sci. 1976. № 271. P. $5-13$.

13. Oda Y., Nakamura S., Oki I., Kato T., Shinagawa H. // Mutat Res. 1985. № 147. P. 219-229.

14. Sambrook J., Fritsch E.F., Maniatis T. Molecular cloning. A laboratory manual. N.Y.: Cold Spring Harbor Lab. Press, 1989. P. 4-16.

15. Kayumov A., Heinrich A., Sharipova M., Iljinskaya O., Forchhammer K. // Microbiology. 2008. V. 154. P. 2348-2355. 16. Fedorova K., Kayumov A., Woyda K., Ilinskaja O., Forchhammer K. // FEBS Lett. 2013. V. 587. P. 1293-1298.

17. Prichard M.N., Jr. Shipman C. // Antiviral Res. 1990. № 14. P. 181-206. 